University of Nebraska - Lincoln

DigitalCommons@University of Nebraska - Lincoln

Faculty Publications from the Harold W. Manter Laboratory of Parasitology

10-1976

\title{
A Redescription of Crassicutis archosargi, a Digenean Exhibiting an Unusual Tegumental Attachment
}

Robin M. Overstreet

Gulf Coast Research Laboratory, robin.overstreet@usm.edu

Follow this and additional works at: https://digitalcommons.unl.edu/parasitologyfacpubs

Part of the Parasitology Commons

Overstreet, Robin M., "A Redescription of Crassicutis archosargi, a Digenean Exhibiting an Unusual Tegumental Attachment" (1976). Faculty Publications from the Harold W. Manter Laboratory of Parasitology. 305.

https://digitalcommons.unl.edu/parasitologyfacpubs/305

This Article is brought to you for free and open access by the Parasitology, Harold W. Manter Laboratory of at DigitalCommons@University of Nebraska - Lincoln. It has been accepted for inclusion in Faculty Publications from the Harold W. Manter Laboratory of Parasitology by an authorized administrator of DigitalCommons@University of Nebraska - Lincoln. 


\title{
A REDESCRIPTION OF CRASSICUTIS ARCHOSARGI, A DIGENEAN EXHIBITING AN UNUSUAL TEGUMENTAL ATTACHMENT*
}

\author{
Robin M. Overstreet \\ Gulf Coast Research Laboratory, Ocean Springs, Mississippi 39564
}

\begin{abstract}
The homalometrine Crassicutis archosargi from the northern Gulf of Mexico is redescribed, and some related digeneans are discussed. Numerous unidentified refractile bodies occurred in the tegument and other tissues of a few specimens of $C$. archosargi, and an intimate relationship between the parasite and its piscine host resulting from a modified tegument is reported for others. Binding by the described adhesive tegument increases the number of known ways digeneans attach to their hosts. Several specimens also harbored a histozoic myxosporidan in several tissues and a flagellate, Hexamita sp., in their ceca.
\end{abstract}

The digenean Crassicutis archosargi Sparks and Thatcher 1960 infects its only known final host, the sheepshead, Archosargus probatocephalus (Walbaum), in Mississippi. Previously, it had been reported only from Grand Isle, Louisiana (Sparks and Thatcher, 1960) and Rockport, Texas (Joy, 1971). Specimens exhibited unusual features. Some possessed refractile bodies in the tegument, others attached to their piscine host by an adhesive tegument, and still others hosted two protozoans. This paper reports those features.

\section{MATERIALS AND METHODS}

Several sheepshead collected by trawl and maintained alive provided fresh parasites. Whole mounts of the trematode were fixed in hot AFA solution under minimal coverslip pressure, stained with Van Cleave's hematoxylin, and mounted in Histoclad or Permount. Treatment of sectioned specimens included a number of histological techniques mentioned in the text; methods followed those described in a manual edited by Luna (1968). I drew illustrations with the aid of a camera lucida and present measurements in micrometers.

\section{DIGENEA}

\section{Crassicutis archosargi Sparks and Thatcher 1960} (Figs. 1-3)

Redescription (based on 46 specimens, many parasitized in various degrees by a myxosporidan,

Received for publication 31 October 1975.

* This study was conducted in cooperation with the U.S. Department of Commerce, NOAA, National Marine Fisheries Service, under PL 88-309, Project No. 2-262-R and NOAA, Office of Sea Grant, under Grant No. 04-6-158-44060. The U. S. Government is authorized to produce and distribute reprints for governmental purposes notwithstanding any copyright notation that may appear hereon. and the holotype, USNM Helm. Coll. No. 39027, for which measurements follow in parentheses): Body yellowish-orange in life, 1,527 to 3,589 $(3,180)$ long by 696 to $1,392(1,090)$ wide at testicular, or widest level. Tegument thick; thickest margin per worm 16 to 45 (12); rugose, especially in forebody; lacking spines. Eyespot pigment sparse, dispersed. Dorso-ventral muscle bundles conspicuously prevalent in many specimens. Oral sucker subterminal, nearly spherical, 133 to 229 (223) long by 139 to 245 (229) wide, with ventral mouth. Sucker-width ratio $1: 1.1$ to 1.5 (1:1.0). Forebody 21 to $31 \%$ of body length. Prepharynx thick-walled, usually more than $1 / 2$ length of pharynx. Pharynx 90 to 162 (113) long by 87 to 157 (135) wide, with inconspicuous anterior band of circular muscles. Esophagus either longer or shorter than pharynx, depending on state of contraction, surrounded by glandular cells. Intestinal bifurcation roughly midway between pharynx and acetabulum; ceca densely epitheliated, terminating 7 to 22 (12)\% of body length from posterior end of body.

Testes tandem, contiguous or nearly so, smooth to lobed in shape; anterior testis 128 to 454 (438) long by 142 to 442 (247) wide; posterior testis 171 to 504 ( 478 ) long by 126 to 422 ( 277 ) wide; posttesticular space 14 to 34 (30)\% of body length. Seminal vesicle saccate, 94 to 345 (>500) long by 58 to 307 (183) wide, occasionally overlapping acetabulum or ovary. Cirrus sac absent, but thin incomplete membrane surrounding prostatic cells near distal (anterior) portion of seminal vesicle; prostatic cells few, most conspicuous around prostatic duct, elongated cells near distal portion of seminal vesicle, small cells sparsely surrounding long muscular hermaphroditic duct; prostatic vesicle with internal anucleated membrane-bound bodies absent, but distinct muscular atrium present with cone-shaped muscular sphincter projecting inwards. Genital pore median or submedian, immediately preacetabular.

Ovary globular to spherical, consistently dextral in all but one specimen, roughly midway between anterior testis and acetabulum, 93 to 215 (206) long by 97 to 204 ( 177 ) wide. Seminal receptacle typically elongate and longer than and overlapping 

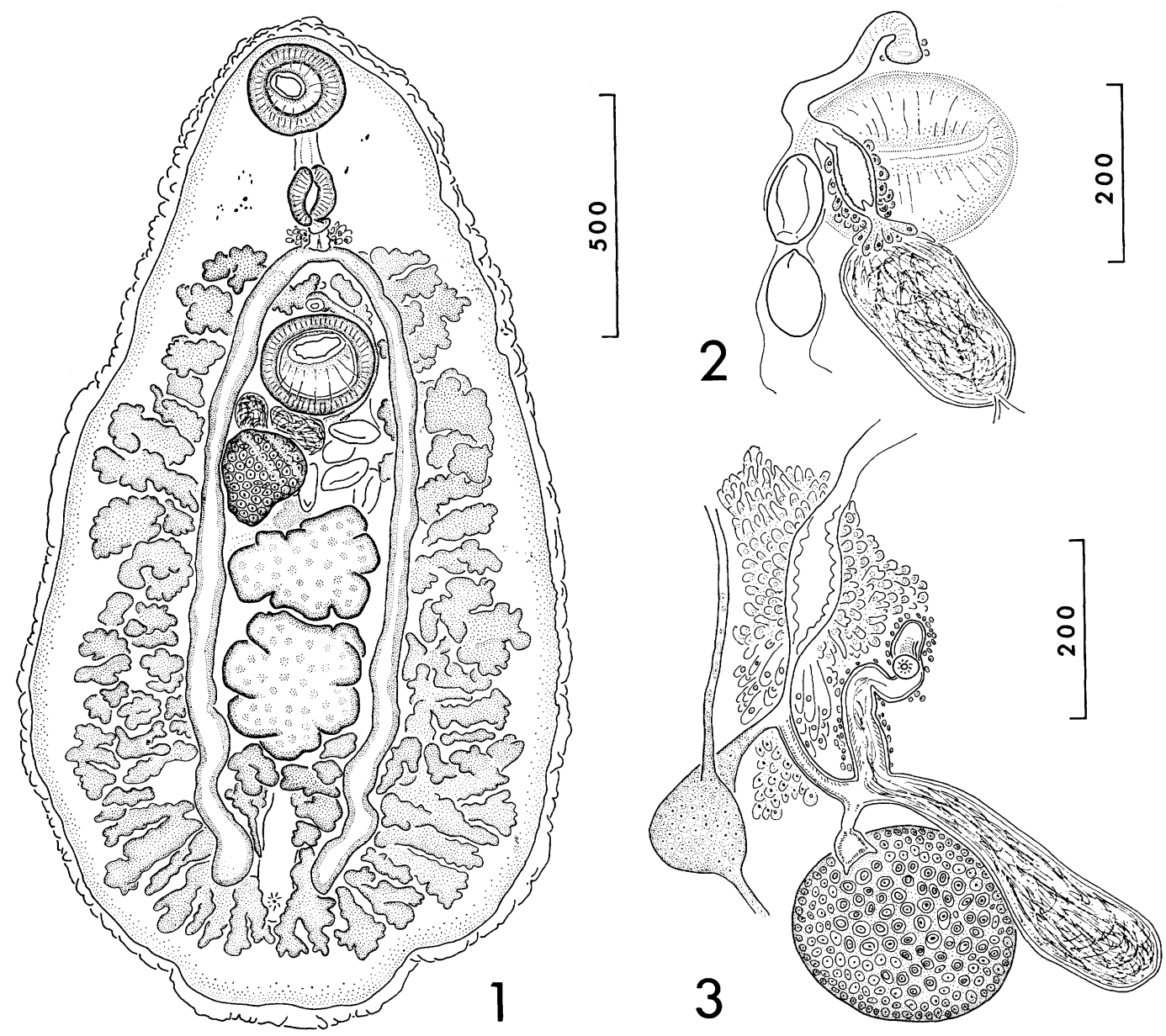

Figures 1-3. Crassicutis archosargi. 1. Whole mount, ventral view. 2. Terminal genitalia, dorsal view. 3. Female reproductive system, dorsal view. Scale values are micrometers.

ovary. Mehlis' gland compact, adjacent to ovary and anterior testis. Laurer's canal muscular. Oviduct with oocapt. Vitellaria consisting of numerous follicles or irregularly-shaped "bands," extending from near posterior end of body forward to well anterior to acetabulum in most specimens, to anterior border of acetabulum in 10 specimens; confluent in hindbody of all specimens and in forebody of majority of them; overlapping ceca dorsally but not ventrally except very small follicles or portions of few large ones in few specimens; seldom extending to near margins. Eggs operculated, with minute projection at anopercular pole, 70 to 129 ( 107 to 129 ) long by 44 to 78 ( 54 to 64 ) wide in partially-collapsed mounted material, 95 to 113 long by 63 to 74 wide from 2 living worms.

Excretory vesicle I-shaped, terminating anteriorly near posterior of rear testis; pore dorsal, subterminal, 5 to 13 (7)\% of body length from posterior end of body.
Host: Archosargus probatocephalus (Walbaum), Sparidae.

Site: Intestine.

Localities: Mississippi Sound and adjacent areas; holotype from Grand Isle, Louisiana.

Specimens deposited: USNM Helm. Coll. No. 74135 ( 2 whole mounts), No. 74136 ( 2 slides with sections ).

\section{Discussion}

The above description adds several diagnostic characteristics to the abbreviated original description (Sparks and Thatcher, 1960), as well as range extensions for measurements. It also adds some illustrations. Unfortunately, the only figure by Sparks and Thatcher has been deleted from the journal, at least those copies I examined. Page 342 of a reprint included it, 
but that page was replaced by reprint-page 343 in the journal. Rather than having large vitelline follicles overlapping the ceca ventrally as suggested in that illustration, there occurs a relatively clear area, and, unlike the paratypes, a thick tegument characterizes all worms collected in Mississippi. A redescription seemed necessary in light of several unreported features of Crassicutis archosargi and the uncertainty of a phylogenetic classification of members of Crassicutis Manter 1936 and related genera.

Manter (1936) originally separated members of his genus from those of Homalometron Stafford 1904 because they lacked both cuticular spines and a prostate gland. Later (1947), he separated them on the basis of "absence of body spines, very thick cuticula, and perhaps also, the anteriorly confluent vitellaria." Even though we now know of some intergradation in characters such as the presence of a few spines in large C. gerridis Nahhas and Cable 1964 and their suspected loss in C. karwarensis Hafeezullah 1970, as well as relatively thick teguments in some species of Homalometron, many characteristics of Crassicutis spp. relate more to species of Apocreadium Manter 1937 than to those of Homalometron. Several species such as A. foliatum (Siddiqi and Cable 1960) Overstreet 1969 (=Homalometron $f$.) have a thick tegument and $A$. longisinosum Manter 1937 and A. cryptum Overstreet 1969 lack tegumental spines. Several species possess features more specific to $C$. archosargi such as $A$. mexicanum Manter 1937, which lacks complete large vitelline follicles ventral to the ceca as apparently does C. cichlasomae Manter 1936, C. opisthoseminis Bravo-Hollis and Arroyo 1962, and C. chuscoi (Pearse 1920) Peters 1957; A. longisinosum and others which are yellowish-orange in life as is $C$. bravoae Jimenez and Caballero 1974; and A. foliatum, A. cryptum, A. manteri Overstreet 1970, and A. caballeroi Bravo-Hollis 1954, which have dorsal subterminal excretory pores as do $C$. cichlasomae and C. opisthoseminis. Members of Apocreadium are separated from those of Neoapocreadium Siddiqi and Cable 1960 on the basis of not possessing vitelline follicles confluent in the forebody. Other characters have been suggested as means of separating the species by Sogandares-Bernal (1959), Siddiqi and Cable (1960), and Yamaguti (1971), but reexamination of specimens and inclusion of additional species nullify those differences.

Members of both Apocreadium and Neoapocreadium differ from those of Crassicutis and Homalometron, which also can be separated from each other by the anterior extent of vitelline follicles, because they possess a lymphatic system. That difference was instrumental in Yamaguti's (1971 and earlier works) decision to consider Apocreadiidae separate from Homalometridae. Discerning the lymphatic system presents difficulties for some species (Overstreet, 1970), and I do not consider its presence or absence in the "lepocreadiids" as listed by Howell (1966) significant enough to delineate families. In C. archo$s a r g i$, where none exists, the ducts transporting vitelline material and membranes surrounding follicular bunches resemble a lymphatic system when not filled with compact material, especially in living material kept in saline for long periods.

In addition to all the above characters which cast doubt on Yamaguti's taxonomic arrangements, some other features of species of Crassicutis present problems. Crassicutis cichlasomae, the type-species, was originally described with diagonal testes and lacking a prostate gland. With the exception of $C$. chuscoi, C. opisthoseminis, and apparently $C$. bravoae, other species all have tandem testes. The related Pancreadium otagoensis Manter 1954 also has diagonal testes, but its excretory vesicle winds between them, and the ovary is deeply lobed. In Trematobrien haplochromios Dollfus 1950, which was shown by Manter (1962) to lack a cirrus sac, the testes are symmetrical, but the ceca unite posteriorly. Crassicutis chuscoi, C. wallini (Pearse 1920) Peters 1957, C. gerridis, my specimen (Overstreet, 1969) of C. marina Manter 1947, and possibly others all have some prostatic cells. Yamaguti (1971), on the basis of the extent of the seminal vesicle, position of the genital pore, and number and size of eggs, removed C. antarcticus Szidat and Graefe 1967 from the genus without transferring it to another genus. Because of the incomplete description of that species, I believe types or additional material need to be examined before the species is treated further. In order for a proper review of Crassicutis, redescriptions of many species 

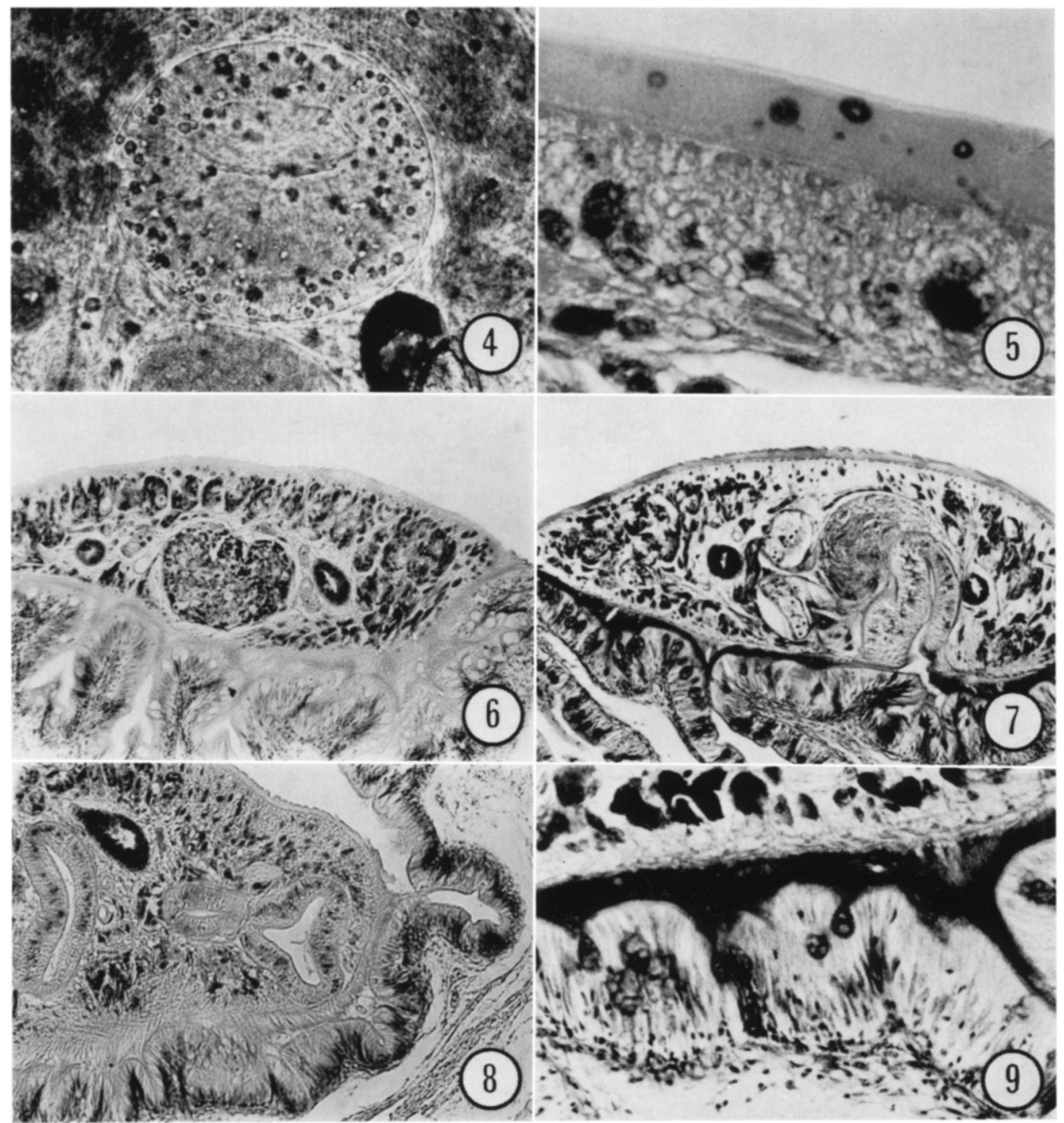

Figures 4-9. Crassicutis archosargi. 4. Refractile bodies situated in and about acetabulum of whole mount, Van Cleave's hematoxylin, $\times$ 170. 5. Sectioned material showing stained refractile bodies in dorsal tegument, Heidenhain's iron hematoxylin, $\times$ 500. 6. Cross section at testicular level showing modified tegument attached to host's intestinal epithelium, Harris' hematoxylin and eosin, $\times 96$. 7. Cross section at acetabular level of same worm, stained by PAS method and digested with diastase, $\times 94$. 8 . Frontal view showing lateral attachment, Harris' hematoxylin and eosin, $\times 94$. 9. Close-up of similarly stained material as in Fig. $7, \times 300$.

described in that and related genera are necessary.

\section{UNIDENTIFIED REFRACTILE BODIES}

Spherical-, subspherical-, and irregularlyshaped refractile bodies, up to $20 \mu \mathrm{m}$ in diameter but averaging about $5 \mu \mathrm{m}$ were conspicuous in some living and mounted specimens.
These bodies were most concentrated in the tegument and acetabular tissue (Fig. 4) and less conspicuous in the parenchyma. Heidenhain's iron hematoxylin revealed most of them to possess a clear crystalline internal region (Fig. 5), but a few showed a darkly stained internal region or ring.

Various histochemical tests of the bodies 
ruled out several components: collagen (Masson's trichrome method and Mallory's phosphotungstic acid hematoxylin method [PTAH]); keratin (Ayoub-Shklar method); calcium (Kossa's method); and iron (Lillie's method for ferric and ferrous iron). The use of McManus' method for glycogen (PAS), the modification of Mowry's 1958 colloidal iron stain for acid mucopolysaccharides, and MayGrunwald Giemsa method also failed to reveal an identifiable component.

The central portion, however, contained material which polarized light as shown with Nicol prisms. This birefringence was most conspicuous using sections stained with Lillie's method for ferric and ferrous iron, but also apparent using Heidenhain's iron hematoxylin and Kossa's method for calcium. Some stains caused the apparent complete disappearance of the polarizing material.

All worms did not possess the refractile bodies. Only worms in a single fish, collected 15 November 1974, harbored the structures, and then only in about 15 of over 100 examined worms. No obvious relationship existed between the bodies and myxosporidan infections.

The function of the bodies is unknown. Because they appeared in few individuals from only one fish, they may be a pathological condition resulting from a host-parasite interaction which originated from a metabolic alteration of that particular host fish or sub-population of C. archosargi. Their cytoplasmic location, shape, and birefringence (Missmahl and Riethmüller, 1967) support an interpretation of being lysosomes, but the bodies measure larger than expected for such structures. Fresh material could not be obtained to investigate for enzymatic properties of these organelles.

On a few occasions, I have observed the same or similar appearing bodies in a few other species of digeneans, but never in as many individuals or in such dense concentrations.

\section{HOST-PARASITE INTERFACE}

Binding some medium-sized trematodes to their host was a tegument with most remarkable adhesive qualities, making mechanical removal from the host's intestinal epithelium difficult. Worms from a few different fish showed this capability, and presumably any-sized worm could attach in a similar manner even though large worms did not occur in examined fish with adhering worms. Small worms observed in such fish, however, attached solely by their two powerful suckers. The unusual tegumental attachment by the medium-sized worms required sectioning of these specimens in situ (Figs. 6-9).

The attaching tegument contrasted sharply in appearance and staining capacity with the unmodified, unattached tegument of the same worm. A substance histologically appearing as a modified syncytial tegument usually comprised the complete distance between the host's epithelial tissue and the worm-proper, often a thickness over five times that of the unmodified tegument. In addition to filling most of the available space between host and worm-proper, this modified tegument cemented many of the host's intestinal crypts together. Usually the ventral side of the worm attached to the host with the acetabulum withdrawn. Attachment along lateral portions of the worm was observed (Fig. 8); presumably any tegumental area, given the proper stimulus, could bind with the host. The modified tegument, as opposed to the remaining unmodified portion, stained positive with the PAS stain both with and without diastase digestion, indicating the presence of material other than glycogen (Figs. $7,9)$. Mayers' mucicarmine stain ruled out its composition by mucin, and Gomori's stain indicated the absence of reticulum. No acid mucopolysaccharides were evident in the tegument using the modification of Mowry's 1958 colloidal iron stain, and the PTAH stain failed to reveal fibrin. Both the modified and unmodified tegument took up the eosin from Harris' hematoxylin and eosin stain (Figs. 6, 8 ), and neither polarized light. In addition to the tinctorial differences between the two portions shown with PAS stain, Masson's trichrome stain also provided a striking difference. The complete thickness of the modified tegument selectively stained with the aniline blue dye.

Immediately underlying the tegument within the parenchyma occurred a birefringent interrupted band. Similar birefringent material also lined the worm's alimentary tract and oral cavity. The disjunct band completely encircled the worm, exhibiting no specific relationship to the modified tegument; it was not collagen or keratin. Preparations stained with Harris' $H$ 
and $\mathrm{E}$ showed the feature intensely with polarization microscopy. Birefringent material among muscle tissue of the pharynx was also evident with Harris' $H$ and $E$ and with diastasedigested sections stained using the PAS method. Birefringent features are already known to characterize various helminths (Wolman, 1975).

Despite the lack of complete histological characterization of the modified tegument, a description of the unique structure deserved attention. The different mode can now be added to the more understood mechanisms of attachment. Various trematodes attach to their hosts by one or more suckers, glands of different types, a strigeoid adhesive organ, modifications of their bodies into cup-like structures, lodgment in host tissue, hooks, spines, and an unusual relationship with the host as described by Leigh (1963). Leigh found that Odhneriotrema incommodum (Leidy 1856) attached to its alligator host in such a way that the tegument of the parasite disappeared at the anterior point of contact, the host's adjacent mucosa became destroyed, and interdigitation appeared to occur between host and parasitic tissues.

Erasmus (1972:248), who studied the intimate relationship between tegument and host of strigeoids, pointed out that local specialization of the tegument can occur. Indeed, a reappraisal of host-parasite interfaces, as he suggested, now appears more necessary, even though the generalized tegumental attachment of C. archosargi is far from universal. Lumsden (1975:297), in his extensive review of helminth surfaces, pointed out that the superficially positioned coat of a digenean tegumental surface varies considerably in morphology and chemistry between different developmental stages of the same species and between comparable stages of different species. The tegument and its surface of $C$. archosargi may provide an important source and tool in understanding variability in composition of a tegument of an adult worm involved with a shift in its functions and, even more important, in recognizing an important biologically adhesive material. Possible functions of the interface other than attachment were not investigated.

\section{PROTOZOANS}

Both heavy and light infections of a myxosporidan occur in tissues of the digenean. Be- cause the parasite represents an undescribed species and because an invertebrate acts as such an unusual host, a separate paper will treat it (Overstreet, 1976).

A symbiotic flagellate identified as Hexamita sp. occurred within the ceca of several individuals. Most conspicuous in small worms, the pyriform protozoan measured about 6 to $7 \mu \mathrm{m}$ long by $4 \mu \mathrm{m}$ wide when alive, not counting its flagella. The flagella extended about the length of the body proper. When fixed, the body retained similar dimensions ( 4 to 7 by 3 to 4 $\mu \mathrm{m})$, but acquired a more ellipsoidal shape. Under stress of microscopic examination, many attached their anterior ends to the trematode's intestinal epithelia and assumed an amorphous shape, sometimes with long filamentous adhesive projections.

Another species of Hexamita Dujardin from a trematode has been reported (Hunninen and Wichterman, 1936; 1938). Measuring 8 to 14 $\mu \mathrm{m}$ long by 3 to $7 \mu \mathrm{m}$ wide, that flagellate infected the eggs, uterus, oviducts, seminal receptacle, vitelline glands, and testes of Deropristis inflata (Molin 1859) Odhner 1902 (Acanthocolpidae) in an eel from Woods Hole, Massachusetts. It inhabited trematodes in 20 of 35 fish with the worm, but not in two other digeneans in the eel nor in the fish's intestine, except in rare cases when feces contained heavily-infected eggs. Over 20 individuals could infect a single egg and infected eggs did not develop miracidia. Manter (1930) observed protozoans from the ceca of Lepocreadium trulla (Linton 1907) Linton 1910 (Lepocreadiidae) from a yellowtail snapper "about the size and shape of Chilomastix." He did not see flagella on the active organisms, but did encounter the protozoan on different occasions. In fixed specimens of Bancroftrema neoceratodi Angel 1966 (Paramphistomidae) from Neoceratodus forsteri (Krefft), Angel (1966) observed between a few and 60 organisms in the ceca of all immature, but not mature, specimens examined. She assumed these $10.5 \mu \mathrm{m}$ by $7 \mu \mathrm{m}$ individuals to be a flagellate with its symbiotic status uncertain.

\section{ACKNOWLEDGMENTS}

I thank Dr. Robert H. Edwards of Keesler Air Force Base for aiding in the histochemistry, Dr. J. Ralph Lichtenfels of the National Para- 
site Collection for loaning type material, and Ronnie G. Palmer, Edward C. Whatley, Jr., and Theresa Ann St. Andrie of the Gulf Coast Research Laboratory for providing technical assistance.

\section{LITERATURE CITED}

ANGEL, L. M. 1966. Bancroftrema neoceratodi, gen. et sp. n., a paramphistomatid trematode from the Australian lungfish. J Parasitol 52: 1058-1961.

Erasmus, D. A. 1972. The Biology of Trematodes. Edward Arnold (Publ.) Ltd., London, $312 \mathrm{p}$.

Howell, M. 1966. A new genus in the family Lepocreadiidae (Trematoda: Digenea) with notes on the status of some taxa within the family. Trans R Soc N Z, Zool 8 : 23-29.

Hunninen, A. V., and R. Wichterman. 1936. Hyperparasitism: A species of Hexamita (Protozoa, Mastigophora) found in the reproductive systems of Deropristis inflata (Trematoda) of marine eels. Biol Bull 71 : 409.

— AND — 1938. Hyperparasitism: A species of Hexamita (Protozoa, Mastigophora) found in the reproductive systems of Deropristis inflata (Trematoda) from marine eels. J Parasitol 24: 95-101.

Joy, J. E. 1971. Geographical distribution and host records for the genus Crassicutis (Trematoda: Allocreadiidae). Folia Parasitol (Praha) 18: 233-234.

LEIGH, W. H. 1963. An unusual host-parasite relationship between Alligator mississipiensis and the trematode Odhneriotrema incommodum (Leidy, 1856). J Parasitol 49 (Suppl.) : 40.

LuMSDEN, R. D. 1975. Surface ultrastructure and cytochemistry of parasitic helminths. Exp Parasitol 37: 267-339.

LunA, L. G. (ED.) 1968. Manual of Histologic Staining Methods of the Armed Forces Institute of Pathology. 3rd ed. The Blakiston Div., McGraw-Hill Book Co., New York, $258 \mathrm{p}$.
Manter, H. W. 1930. Studies on the trematodes of Tortugas fishes. Carnegie Inst Washington Yearb No 29: 338-340.

__ 1936. Some trematodes of cenote fish from Yucatan. Carnegie Inst Washington Publ No 457 : 33-38.

- 1947. The digenetic trematodes of marine fishes of Tortugas, Florida. Am Midl Nat 38: 257-416.

- 1962. Notes on the taxonomy of certain digenetic trematodes of South American freshwater fishes. Proc Helminthol Soc Wash 29: 97-102.

Missmahl, H. P., and G. Riethmüller. 1967. Lysosomen: untersuchungen zur feinstruktur und einfacher polarisationsoptischer nachweis. Blut 15: 198.

Overstreet, R. M. 1969. Digenetic trematodes of marine teleost fishes from Biscayne Bay, Florida. Tulane Stud Zool Bot 15: 119-175.

- 1970. Two new species of Digenea from the spot, Leiostomus xanthurus Lacépède, from the Gulf of Mexico. J Parasitol 56: 10551057.

-1976. Fabespora vermicola sp. n., the first myxosporidan from a platyhelminth. J Parasitol 62: 680-684.

Siddiqi, A. H., and R. M. Cable. 1960. Digenetic trematodes of marine fishes of Puerto Rico. Sci Surv Porto Rico and Virgin Islands 17: 257-369.

Sogandares-Bernal, F. 1959. Digenetic trematodes of marine fishes from the Gulf of Panama and Bimini, British West Indies. Tulane Stud Zool 7: 69-117.

Sparks, A. K., and V. E. Thatcher. 1960. A new species of Crassicutis (Trematoda, Allocreadiidae) from a sparid fish (Archosargus probatocephalus) in the northern Gulf of Mexico. Trans Am Microsc Soc 79: 341-342 [Reprint paginated 341-343].

Wolman, M. 1975. Polarized light microscopy as a tool of diagnostic pathology. A review. J Histochem Cytochem 23: 21-50.

Yamaguti, S. 1971. Synopsis of Digenetic Trematodes of Vertebrates. Vols I-II. Keigaku Publ Co, Tokyo, 1074 p., 349 pls. 